Barbara Kucharska

Mirostawa Malinowska

University of Economics in Katowice

\title{
TRENDS IN Y GENERATION'S BEHAVIOUR ON THE FOOD MARKET
}

The aim of the article is to identify $Y$ generation's behaviour on the food market in the context of dominant consumer trends. The purpose of the article was accomplished by literature studies, information from branch magazines and direct research carried out by the authors of the article. Identification of consumer trends was made on the basis of secondary sources of information, using also the report Top 10 Global Consumer Trends 2019 by Euromonitor International. The report also became an inspiration to undertake direct research, which was carried out using the auditorium survey technique among representatives of the Y generation. The results of research and analysis indicate that the $Y$ generation referred to as "yummy" is an extremely important entity on the food market - large, young, innovative, active, fast, demanding, unique and very important for the supply entities on the food market. The behaviour of this group of consumers determines contemporary trends on the market and the necessity to undertake activities consistent with these trends in terms of the offer, its availability, as well as diversity and price.

Key words : generation $Y$, consumer behaviour, food market, trends

JEL Code: D11 D12 J11

\section{Introduction}

Generation $\mathrm{Y}$ is the generation of young people forming a market segment that is extremely important for food supply entities, especially food producers and retailers, as well as providers of catering services. In the literature different dates are taken into consideration while describing Y generation and it concerns both initial and final dates of time interval (from 1977 to 2000) ${ }^{1}$. The size of the segment and its specific character means that generation $\mathrm{Y}$ has, and is going to have in the future, a significant impact on how the market functions. These are the reasons for implementation of research supporting recognition of not only behaviours of generation $\mathrm{Y}$ consumers on the food market, but also trends prevailing within these behaviours.

According to the report Top 10 Global Consumer Trends 2019, the most important consumer trends in 2019 still include those that derive from post-modernist determinants of consumption and development of information technologies. Post-modernist consumers are those for whom freedom is the most important catchword, while multi-

${ }^{1}$ M. Bartlett, Analyst: understanding what shapes generation can help the... . Credit Union Journal, No. 8(21)/2004; P. Dalton, Managing the generation. ABA Washington News, No. 11(19)/2003; R. K. Miller, K. Washington, Consumer Behavior 2011: Millennial Consumers, Richard K. Miller and Associates (RKMA), Loganville 2011; M. Rich, Millennial students and technology choices for information searching. The Electronic Journal of Business Research Methods, No. 6(1)/2008. 
dimensional consumer mobility (social, professional, spatial) and growing interest in products that enable this mobility are the consequence of this freedom ${ }^{2}$. The expression of new consumption and the phenomena it is accompanied by are some of the trends that are revealed with special intensity. Among them, ecologisation, deconsumption, virtualisation and mediatisation are of key importance ${ }^{3}$.

The goal of the paper is to identify behaviours of generation $\mathrm{Y}$ on the food market in the context of mainstream consumer trends. The paper objectives are implemented through literature studies, information from sector journals and direct research conducted by the authors of the paper. Identification of consumer trends is performed on the basis of secondary information sources while applying the report Top 10 Global Consumer Trends 2019 by Euromonitor International, among others. The Report also became an inspiration for implementation of direct research that was performed with the use of the technique of auditory interview among the youngest representatives of generation $\mathrm{Y}^{4}{ }^{4}$

\section{Generation Y on the food market - "yummy generation"}

Identification of generations in society is a complex issue and does not result only from attributing dates to a given part of the population. In sociological terms generations are not only different with respect to their biological age, but firstly they vary in the way that identified groups are clearly different from each other with respect to their attitudes, opinions, shared values, aspirations, lifestyle, etc. This mainly refers to differences, the source of which are diverse experiences (the so-called shared generation experience) and life perspectives. Differences between generations occur in all societies, but in those in which rapid and deep changes occur or those that experience disasters (wars, revolutions) affecting various age groups with a different intensity, they are sometimes really dramatic and have serious consequences (the phenomena of generation gap, conflict of generations, etc.). Despite difficulties in defining generations accurately, the notion is often applied by researchers of modern societies while explaining the phenomena of collective behaviour, revolutionary movements, new phenomena in art, moral changes, etc. ${ }^{5}$

Therefore the notion of generation can represent a group of people of similar age who have experienced similar events, and have been brought up in similar conditions and time. ${ }^{6}$ The specific character of generation $\mathrm{Y}$ is a result of contemporary political,

\footnotetext{
${ }^{2}$ I. Sowa: Nowe trendy w zachowaniach młodych konsumentów wyzwaniem dla współczesnego handlu [New trends in behaviours of young consumers as a challenge to contemporary trade]. Zeszyty Naukowe Uniwersytetu Szczecińskiego nr 777. Problemy Zarządzania, Finansów i Marketingu [Issues in Management, Finances and Marketing] nr 32/2013, pp. 530-533

${ }^{3} \mathrm{Cz}$. Bywalec: Konsumpcja a rozwój gospodarczy i społeczny [Consumption and economic and social development], C.H.Beck, Warszawa 2010, p.195

${ }^{4}$ Due to restrictions related to the length of the paper, it only presents a part of results of direct research conducted in this area by the authors of the paper. The research was conducted within the project to maintain research potential of the University of Economics in Katowice titled "Food consumption models changes in Poland (2018-2019), Market and Consumption Department.

${ }^{5}$ [www1] https://encyklopedia.pwn.pl/haslo/pokolenie;3959194.html

${ }^{6}$ M. Baran, M. Kłos: Pokolenie Y - prawdy i mity w kontekście zarządzania pokoleniami [Generation $Y$ truths and myths in the context of generation management], Marketing i Rynek 5/2014, p. 924.
} 
cultural, economic and firstly technological processes. ${ }^{7}$ Therefore the generation can be described from demographic, historical, technological and socio-cultural perspective. Assuming that generation Y in Poland represents people born in the 1980s and $1990 \mathrm{~s}^{8}$, it can be stated that this group constitutes around a quarter of the country's population. Furthermore, they are grown up, yet young people (the youngest representative is 19 now, and the oldest 39 years old) and they are well educated. The size of this segment and its specific character in terms of demography means that the people from this generation have and are going to have significant impact on the functioning of the whole society now and in the future.

Millennials have a different attitude to migration, change of the place of living and work that is a natural element of life.

Technological perspective seems to be vital for the analysis of generation Y. For the members of this generation, IT technologies are something natural and indispensable, a necessary connection with the surrounding world for the purpose of real and / or virtual participation in it. For this generation proficiency in the use of modern IT devices is nothing extraordinary. Thanks to IT they have access to various resources at the same time, and they can perform a lot of tasks at the same time. Therefore they are called multi-taskers. Thanks to the Internet, they have access to broad knowledge resources, everywhere and at any moment (similarly to other generations). However, they often succumb to the illusion that they have access to the whole of knowledge and competences - they are the generation that does not need mentors or intermediaries in the access to knowledge or culture. For representatives of generation Y, the Internet is not only a source of information but also a space to exchange experiences and information.

Looking at this generation from a socio-cultural perspective, it can be noticed that people representing it delay the "moment of leaving the family" and establishing their own household. They consider themselves tolerant, they show interest and concern about other people, they are willing to think positively, and they manifest significant flexibility. They consider themselves glad and happy. A broad circle of friends, health, fame and material success are priorities for them. They do well in stressful situations. They are also often described as impatient and demanding people oriented on achievement of quick results. ${ }^{9}$ They are mobile not only in virtual terms as they travel a lot.

There is no compliance regarding precise establishment of dates for generation $\mathrm{Y}$ in the literature, because of differences occurring between various countries in the sphere of ICT implementation, political changes, etc. There are no explicit guidelines concerning determination of specific dates for the same society segment, but there is an

\footnotetext{
${ }^{7}$ P. Kisiel:, Millenialsi - nowy uczestnik życia społecznego [Millennials - a new participant of social life], Studia Socialia Cracoviensia 8 (2016) nr 1., p.93.

${ }^{8}$ In the literature, various time frames are adopted for this generation, however it is often assumed that generation Y (often called the generation of millennials) is represented by people born between 1980 and 1999 .

${ }^{9}$ P. Kisiel: Millenialsi - nowy uczestnik życia społecznego... [Millennials - a new participant in social life], op. cit., pp 85-91.
} 
agreement between researchers concerning features describing this generation ${ }^{10}$. Millennials (as they are often described) are active, well-educated people, willing to continue their development. They use new technologies in every area of life, and thanks to the access to the Internet, they are "World citizens" - they have friends all over the world. They are self-confident and at the same time tolerant and open. They attach great importance to the quality of life or experience, but not to possessing. They are convinced about their exceptionality and they have high self-esteem which makes them a little resistant to criticism. They also have high ecological awareness. Generation Y consumers are characterised by smartness and being very-well informed about market offers thanks to the use of new technologies that support gathering information ${ }^{11}$. Millennials know the trends reigning on the market and willingly perform transactions with the use of the Internet. They also search for bargains and use personalised products. Quality is not always the most important for them. What counts is firstly their own, original style that should be provided by brands. They like novelties and value companies that often launch novelties on the market. ${ }^{12}$

From the point of view of their behaviour on the food market, Generation Y can be called a "yummy generation", "foodies" and "yummymers", as they are fascinated with food. ${ }^{13}$ Sometimes the members of this generation are called the generation of food maniacs. Shopping for food is a way of spending free time, preparing meals is a hobby and eating them is a real pleasure. For them, not only the taste of food is important but also its look. They are pioneers in using unconventional ingredients and spices, as well as services of unconventional catering services (sushi, fit style cuisine, etc.). They also take pictures of meals that are self-made or ordered in restaurants and share them on social networking sites.

Analysing behaviours of this generation on food market it should be emphasised that "yummymy" consumers are interested in regional products and they pay attention to what they eat ${ }^{14}$. Product authenticity, traditional methods of production and its local character are extremely important for them. It is also important for them where the products come from and the fact that they are Polish. They draw inspiration from foreign cuisines, they read, observe and introduce new meals in their menu. They are pioneers of diverse grocery novelties. Healthy food fashion is observed among this group of consumers - they are in favour of "slow food" which does not mean that they do not eat "fast food". They eagerly visit "fast casual" restaurants that offer higher product quality and better décor than traditional "fast food" restaurants, but at the same time the service is fast. They also spend more on food in comparison with the previous generations - they choose food products of high quality that are definitely more expensive, and they often eat out while appreciating culinary experiments at home at the same time. They are interested in products that are truly "bio", "eco" and not just labelled in this way. They

\footnotetext{
${ }^{10}$ E. Gołąb-Andrzejak: Konsumenci pokolenia Y - nowe wyzwanie dla komunikacji marketingowej [Generation Y consumers - a new challenge for marketing communication], Handel Wewnętrzny 2016/2, p. 141.

${ }^{11}$ E. Gołąb-Andrzejak: Konsumenci pokolenia ... [Generation consumers...] of op.cit., p. 143.

${ }^{12}$ [www2]

${ }^{13}$ On the subject of generation Y [www3] [www4] [www5] [www6][www7][www8]

${ }^{14}$ [www3] [www4] [www5] [www6][www7][www8]
} 
are more aware consumers who rarely get attached to a specific store or restaurant. "Yummymy" consumers read the labels as well as ingredients of meals, and increasingly more often they look for products with no artificial additives that are sold in ecological packaging.

Generation Y look for products of rather high quality with respect to their nutritional values and taste qualities. They also concentrate on maximisation of the price to quality ratio. "Yummy" consumers are engaged, i.e. they want to help companies in the process of preparation and development of products or offer and have impact on its shape. Contrary to what can be expected, millennials most willingly buy food in brick-andmortar stores. Online shopping in this category is growing but it mainly concerns products with long "use by" dates, simple products that are inconvenient to transport as well as exotic or exclusive products that are not available in brick-and-mortar stores. Comfort and product availability are most important determinants of the choice of the store, whereas the product price is less important. Therefore, "yummymy" generation often do shopping in "convenience" type stores, and they do smaller shopping but more frequently than other generations. "Yummymy" generation is also more likely to buy food in local stores - there they can find unique products, products of local manufacturers and a broad range of local, unique and "non-mass" food brands that millennials could be interested in.

Generation Y also often is referred to as the "digital generation", digital natives, appreciate all technological facilities that enable product purchase (applications, price comparison engines, simulations, culinary and food advice, inspirations) and the possibility to share an opinion on social networking sites and websites with stores and restaurants. They are aware of the power of their opinions and their impact on others; therefore they expect virtualisation from producers, stores, restaurants and offers that would enable them to benefit from the possibility of integration between the real and virtual world.

\section{Trends in consumer behaviour in the context of the food market}

Changes in consumer behaviours are a result of transformations occurring in the group of factors determining these behaviours, i.e. factors related to consumers, the household they are a part of, as well as the environment in which they function. The trends that create new market conditions and affect decision-making in the sphere of food consumption, and consequently also concerning its purchase, processing and storing, as well as using catering services are especially important for generation $\mathrm{Y}$ consumers.

According to the Top 10 Global Consumer Trends 2019 report, the most important trends in consumer behaviours in 2019 still include those that derive from postmodernist determinants of consumption and development of information technologies. Post-modernist consumers are those for whom freedom is the most important keyword and value and multidimensional consumer mobility (social, professional and spatial) as well as growing interest in products that enable this mobility are the consequence of this 
freedom ${ }^{15}$. The expression of new consumption and the phenomena it is accompanied by are some of the trends that are developing very extensively. Among them, ecologisation, individualisation, deconsumption, virtualisation or mediatisation have key significance ${ }^{16}$.

The majority of presented trends in consumer behaviours (Table 1) is most often a continuation of the phenomena previously recognised and described in the literature on the subject, however, the phenomena undergo some modifications, or they adopt new forms. The trends that in a great extent show consumers' care about their well-being, quality of life and the possibility to ensure self-control are especially vital.

Table 1. Most important trends in consumer behaviours, essential from the perspective of the food market

\begin{tabular}{|c|c|}
\hline Specification & Behaviours of food consumers \\
\hline $\begin{array}{l}\text { Everyone's } \\
\text { an expert }\end{array}$ & $\begin{array}{l}\text { Considerable consumer demand of digital consumers on knowledge absorption and } \\
\text { sharing is at the basis of this trend. Fast and unlimited access to information encourages } \\
\text { the consumers to conduct their own research enabling the choice of the offer that is best } \\
\text { for them - the highest quality for the lowest price. Consumers explore, discover and use } \\
\text { great amounts of information, and other consumers are often one of their most important } \\
\text { sources. Their experiences, reviews and advice become invaluable. The trends are } \\
\text { favoured by social media that constitute the platform of information exchange and that } \\
\text { has brought new meaning to the notion of information spread by word of mouth. The } \\
\text { possibility to express opinions about an offer provided to users by enterprises but also to } \\
\text { establish contacts with professionals in a given area are becoming the basis for building } \\
\text { confidence and loyalty. } \\
\text { The number of opinions and difficulty in recognising their authenticity is a problem for } \\
\text { consumers. } \\
\text { The possibility to disseminate information means that consumers can be the best } \\
\text { product/producer/retailer promoter or its worst PR person. } \\
\text { The trend especially concerns products/services related to consumers' hobbies, including } \\
\text { cooking or using catering services among others. }\end{array}$ \\
\hline $\begin{array}{l}\text { I can look } \\
\text { after myself }\end{array}$ & $\begin{array}{l}\text { The trend is an expression of consumer endeavours to ensure and / or regain the sense of } \\
\text { full control over their own life both in physical and emotional dimensions. Consumers } \\
\text { equipped with appropriate tools (including applications) while having access to } \\
\text { information sources, can find / develop solutions to their problems themselves. They are } \\
\text { self-sufficient in this sphere. They are able to take care of themselves. } \\
\text { For the consumers, health, happiness and simplicity are the priority they can pay more to } \\
\text { have. } \\
\text { The trend is a response to the excess of often contradictory information and an expression } \\
\text { of growing awareness, striving to manipulate it in social media. Personal, individual } \\
\text { consumers' needs are important. Personalisation has great importance }{ }^{17} \text {. }\end{array}$ \\
\hline $\begin{array}{l}\text { Economics of } \\
\text { haste - } \\
\text { instead of "I } \\
\text { want it". "I } \\
\text { want it now"; }\end{array}$ & $\begin{array}{l}\text { Consumers' expectations concern the immediate possibility of access to the very offer as } \\
\text { well as information about the offer. The syndrome of immediate gratification, speed of } \\
\text { consumers' life and the lifestyle - assessed by them in terms of efficiency and } \\
\text { effectiveness contribute to the growth of these expectations. Consumers expect from } \\
\text { enterprises, the solutions enabling to save time and spend it on professional and / or social }\end{array}$ \\
\hline
\end{tabular}

${ }^{15}$ I. Sowa: Nowe trendy w zachowaniach młodych konsumentów wyzwaniem dla współczesnego handlu [New trends in behaviours of young consumers as a challenge to contemporary trade]. Zeszyty Naukowe Uniwersytetu Szczecińskiego nr 777. Problemy Zarządzania, Finansów i Marketingu nr 32/2013, pp. 530-533 ${ }^{16} \mathrm{Cz}$. Bywalec: Konsumpcja a rozwój gospodarczy i społeczny [Consumption and economic as well social development], C.H.Beck, Warszawa 2010,p.195

${ }^{17}$ For example My spoon Guru UK app allows to create a personalised profile with respect to dietary preferences through over 180 various tags. Tellspec Canada - a manual scanner that offers food testing in real time, food safety and food authenticity. 


\begin{tabular}{|c|c|}
\hline $\begin{array}{l}\text { ency- } \\
\text { lifestyle }\end{array}$ & $\begin{array}{l}\text { life. Consumers expect mobile applications that help to organise their life better through } \\
\text { making queues shorter, synchronisation of preferences and personal data management } \\
\text { among others. }\end{array}$ \\
\hline $\begin{array}{l}\text { Back to } \\
\text { basics for } \\
\text { status }\end{array}$ & $\begin{array}{l}\text { Consumers expect simple and transparent solutions and elimination of all these elements } \\
\text { or solutions that have negative impact on their health and life. They aim to regain control } \\
\text { over what they eat, drink or put on their skin. They want only necessary product } \\
\text { ingredients adjusted to their needs to be used. They appreciate the possibility to interfere } \\
\text { with the composition of the products such as food or cosmetics. The rule that "the less, } \\
\text { the better, the more transparent" is prevailing. This trend also refers to the packaging. } \\
\text { Product composition should be clearly exposed on the front of the packaging (some } \\
\text { cosmetic companies limit the number of used ingredients to 5), and the very packaging } \\
\text { should be ecological, reusable or suitable for recycling. It is strongly associated with the } \\
\text { previous "health" or "wellness" trend expressed in buying safe food and ecological food, } \\
\text { paying attention to product composition, quality/freshness of products, drinking a lot of } \\
\text { liquids, using professional dietary advice or controlling the diet of household members. }\end{array}$ \\
\hline $\begin{array}{l}\text { I want a } \\
\text { plastic-free } \\
\text { world }\end{array}$ & $\begin{array}{l}\text { Consumers expect eliminating or at least reducing the use of plastics. They are willing to } \\
\text { pay more for ecological products and those that can be recycled. Plastic became a } \\
\text { preferred packaging material due to many reasons, including versality of use, durability } \\
\text { and the possibility to secure food against being wasted. The level of its recovery, } \\
\text { recycling and reuse is insufficient. There is not enough consumer knowledge about what } \\
\text { can be recycled. }\end{array}$ \\
\hline $\begin{array}{l}\text { Conscious } \\
\text { consumers }\end{array}$ & $\begin{array}{l}\text { Consumers search for the ways to make reasonable decisions concerning what they buy } \\
\text { and look for solutions for the negative impact that consumerism has on the world. This } \\
\text { attitude, full of respect and sympathy, comprises care about other people, animals and the } \\
\text { environment. The trend is represented by people caring about health, interested in well- } \\
\text { being of animals, as well as people who notice the negative impact of enterprises on the } \\
\text { natural environment. Aware consumers do not need to manifest radical attitudes, but they } \\
\text { can behave in a flexible way, e.g. they eliminate products of animal origin from their diet } \\
\text { in a specific time. } \\
\text { Consumers choose not only a healthy but also ethical lifestyle (e.g. protest against testing } \\
\text { products on animals, selected methods of animal farming, growth of demand on } \\
\text { ingredients of plant origin, veganism, vegetarianism). Information about non-applying } \\
\text { practices harming the environment and well-being of animals is important. }\end{array}$ \\
\hline $\begin{array}{l}\text { Finding my } \\
\text { JOMO }^{18} \\
\text { (joy of } \\
\text { missing out) }\end{array}$ & $\begin{array}{l}\text { Consumers aim to determine the boundaries of their privacy. They reduce the time spent } \\
\text { on the Internet and limit or eliminate posting information about their private life and } \\
\text { special events they participate in. They highly appreciate offline contacts - visit to a brick } \\
\text { and mortar store, place of rest and recreation with no access to Wi-Fi network and } \\
\text { establishment of privacy at non-professional time and space. Planned switching off from } \\
\text { virtual space provides consumers with time and reflection regarding what they want and } \\
\text { like doing. Consumers do not aim at total isolation from the rest of the world but try to } \\
\text { limit compulsory interactions. } \\
\text { Consumers' fear of blurring of boundaries between private and social life, effectiveness of } \\
\text { personal data, interference with consumer behaviours, pressure of social networking } \\
\text { portals (the necessity to do exciting things and sharing information about these events } \\
\text { with others to be accepted) are the causes of the trend. Access to the Internet and social } \\
\text { networking sites transformed using social networking sites into a form of obligation. Life } \\
\text { has become an obligation to fulfil expectations of others for } 24 \text { hours / } 7 \text { days a week. } \\
\text { So far, the trend is referred to as "slowing down to the speed of life", } \\
\text { "escape from new technologies" comprised in deconsumption - conscious limiting of } \\
\text { consumption to rational size, compliant with natural, individual, physical and psychical } \\
\text { features of consumers, unwillingness towards mass consumption and } \\
\text { smart shopping - rational planning of household budget through buying necessary }\end{array}$ \\
\hline
\end{tabular}

${ }^{18}$ The sense of satisfaction related to the escape from the mass of information, restricted application of mobile devices and social media. It is the opposite to FOMO (fear of missing out), i.e. the fear of being neglected (lack of information, experience or chances for interaction). 


\begin{tabular}{|l|l|}
\hline & products at a low price ("expect more, pay less") \\
\hline & $\begin{array}{l}\text { Consumers appreciate the possibility to establish and maintain private, social and } \\
\text { professional contacts in virtual space. The possibility to solve problems without the need } \\
\text { to organise direct meetings is important for them. Virtualisation of consumers' life } \\
\text { concerns both the use of professional services (medicine, law, education, state } \\
\text { administration), and their private sphere. The boundary between what can be done off and } \\
\text { online in institutions is shifted. Multidimensional interactions and collective digital } \\
\text { together } \\
\text { experiences both with friends and unknown people - while creating and experiencing } \\
\text { things in a digital way together when they are separated are important. It is possible } \\
\text { thanks to virtual technologies and further development of virtual forms of } \\
\text { communication. The scope of actions that consumers can perform together digitally is } \\
\text { growing. } \\
\text { Continuation and evolution of previous trends defined as overlapping of virtual and real } \\
\text { world, "eat, pray and use innovative technologies" or the trend of "the need to establish } \\
\text { contacts" or "sensuality". }\end{array}$
\end{tabular}

Source: Authors' own case study based on: A.Angus., G. Westbrook: Top 10 Global Consumer Trends 2019. Euromonitor International, 2019; B.Kucharska: Innowacje $w$ handlu detalicznym $w$ kreowaniu wartości dla klienta [Innovations in retail trade in creation of value for consumer]. Uniwersytet Ekonomiczny w Katowicach, Katowice, pp. 83-86), Polski rynek handlu spożywczego w 2010-2020 roku [Polish market of food trade in 2010-2020], 2016.

Other important trends include those associated with virtualisation of consumer life in its many aspects, which is supported not only by general access to mobile devices but also development of the possibilities of their use. Consumers still use the Internet as the place of finding and sharing information, knowledge acquisition, sharing opinions and the area of collective action. Their actions more and more intensely indicate valuing privacy, defining boundaries between private and social or professional life, and return to simplicity and transparency of solutions. Both virtualisation of behaviours and temporary switch-off from the online world takes place for the welfare of the very consumers, their family and society, as well as well-being of animals.

\section{Generation $Y$ on the food market - field research results}

In order to identify selected elements of generation $\mathrm{Y}$ behaviour on the food market, in January 2019 field research was conducted among the youngest representatives of this group of consumers. The research used a traditional technique - an auditorium survey, which was conducted among 318 students studying in Katowice (full-time and part-time students).

The questionnaire contained 9 substantive questions and 11 metrics questions. Closed questions, open questions and scales were used. The aim of the research was to identify selected elements of Y Generation consumer behaviour of in particular, the products and food services that they buy, how they proceed with the purchase, places of food purchase and visited restaurants. The research was also aimed at identifying the importance of sales solutions for customers used by enterprises on the food market and the degree of use of these solutions by the respondents.

The age (people born between 1981-1999) was the criterion for selecting respondents to the sample. The respondent's average age was 22,7 years. The sample included $64 \%$ women and $36 \%$ men. Over $83 \%$ of respondents have secondary education, and the remaining part - higher. Over half of the respondents are professionally active people. Almost $65 \%$ of respondents assess their financial situation 
as good, and $17 \%$ - as very good. Around $18 \%$ consider it to be sufficient. Over $40 \%$ of respondents live in a large city (over 100,000 inhabitants), 27\% are rural residents, Average number of people in households surveyed is 3,3. Respondents assess their participation in the purchase decisions of food in their households at the level of 50,4\%.

The list of declared (mentioned) food products purchased by the respondents consisted of 44 items, which were then assigned by the researchers to product groups (Table 2). Most often it was dairy (64\%), vegetables (55\%), bread $(53 \%)$ and fruit $(48 \%)$.

Table 2. Food products most often bought by respondents (in \%)

\begin{tabular}{|l|r|}
\hline \multicolumn{1}{|c|}{ Specification } & \multicolumn{1}{|c|}{ Total sample } \\
\hline Dairy products, including cheese (12.1\%), milk (9.7\%) & 64,0 \\
\hline Vegetables & 55,4 \\
\hline Bread & 53,4 \\
\hline Fruits & 48,2 \\
\hline Meat & 40,0 \\
\hline Non-alcoholic drinks, including water (9.7\%) & 18,6 \\
\hline Sausages & 15,0 \\
\hline Sweets, including cakes, ice cream (5.6\%) & 14,7 \\
\hline Powdery products & 12,9 \\
\hline Pasta & 11,3 \\
\hline Ready-to-eat products, fast food products, pizza, vegetable creams, fries, sandwiches & 10,1 \\
\hline Gluten-free, sugar-free, unprocessed, vegan, eco products & 4,9 \\
\hline Fish & 3,6 \\
\hline $\begin{array}{l}\text { Other: sauces, spices, ketchup, appetizers, chips, alcoholic drinks, beer, nuts, energy } \\
\text { drinks, semi-finished products, various cuisines of the world, coffee, tea }\end{array}$ & 9,2 \\
\hline
\end{tabular}

Source: Authors' own elaboration based on field research.

The respondents were also asked to specify the ways in which they purchase food (including purchases at stores and online shopping using various facilities (mobile applications or websites). Research results indicate that respondents buy food mainly in stationary stores (98\%). They mentioned from the name or described a total of 44 different places for buying food. Biedronka (68\%) and Lidl (62\%) are the stores most frequently indicated by the respondents. Every fourth respondent purchases in Tesco (24\%) and Auchan (23\%), and slightly less - in Kaufland (17\%). Among the spontaneous names of stores where respondents buy food, there are also smaller outlets $13 \%$ buy in Żabka, which is a convenience store, about $8 \%$ make purchases in Lewiatan, Carrefour and Aldi stores.

Respondents declare purchasing food mostly in conventional retail formats (discount shops, supermarkets, hypermarkets). These outlets offer wide and differentiated range of food products, thus every group of buyers can find the assortment adapted to its expectations. ${ }^{19}$ Additionally, food buyers, when purchasing food products, often tend to choose the shop most relevant to the location. Almost $7 \%$ of respondents did not mention the name of the store, specifying it in the categories "small" or "local ". Only about $12 \%$ of respondents buy food using websites of stationary stores, slightly less

${ }^{19}$ B. Kucharska, Food in retailers' commercial offer - possibilities of building relationships with consumers, Olsztyn Economic Journal, nr 14/2019, s. 313-324. 
(9\%) buy in online stores. In order to purchase food, the respondents also use the applications offered by stationary stores (about $8 \%$ ), and online stores (4\%).

Table 3. Catering services - the most frequently used by respondents (in\%)

\begin{tabular}{|l|r|}
\hline \multicolumn{1}{|c|}{ Specification } & Total sample \\
\hline \multicolumn{1}{|c|}{ Dishes } & 36,3 \\
\hline Pizza & 27,6 \\
\hline fast-food, burger, hamburger, hot-dog, French fries, casseroles & 25,0 \\
\hline Lunch & 9,8 \\
\hline Kebab & 7,5 \\
\hline Chinese cuisine, Thai cuisine, world cuisines, sushi, seafood & 7,2 \\
\hline coffee, tea & 6,4 \\
\hline pancakes, dumplings, spaghetti, pasta, tortilla & 5,9 \\
\hline cakes, desserts, ice cream & 4,6 \\
\hline healthy food, box diet, salads & 2,6 \\
\hline other: dinners, breakfasts, bagels, sandwiches, beer, dishes by weight, cocktails & 15,3 \\
\hline \multicolumn{2}{|c|}{ Places / ways of using catering services } \\
\hline food with delivery & 13,9 \\
\hline restaurants & 5,6 \\
\hline coffeehouses & 4,9 \\
\hline other: bars, pubs, catering & \\
\hline
\end{tabular}

Source: Authors' own elaboration based on field research.

Declarations of respondents regarding the use of catering services should be attributed to both the offer and the places / ways of consumption. The respondents mentioned a total of 44 catering services. The most often mentioned were pizza $(36 \%)$, fast-food dishes (28\%) and dinner dishes (25\%), (table 3 ).

Respondents also had the opportunity to indicate their typical behaviour regarding catering services and to indicate the types of visited places. Most of the respondents buy services at catering places (82,\%), but over half of orders cover home delivery - 56\% use the website for this purpose, and $27 \%$ use the mobile application. Almost $10 \%$ of respondents order dishes by phone with home delivery. In addition, some consumers use interactive kiosks $(7 \%)$, the Internet $(3 \%)$ and mobile applications to order meals consumed in the catering place. Most respondents use the services of restaurants $(71 \%)$, cafes $(60 \%)$ pizzerias $(57 \%)$ and fast food bars $(57 \%)$. The respondents are also customers of ice cream parlours (13\%), milk bars (6\%) and food trucks (6\%). The largest number of respondents (36\%) stated that they eat at McDonald's, a little more than $19 \%$ at Pizza Hut, and $16 \%$ - at KFC. The respondents also visit such institutions as Aioli (7.4\%), Pizza Dominium (5\%) and Dagrasso (4\%). They are also customers of cafes such as Starbucks and Costa Cafe. At the same time the catering places mentioned by the respondents include a lot of local places offering various meals from many regions of the world, different types of meals (vegan, vegetarian,) with different levels of customer service. Respondents asked about the most visited catering places mentioned 283 different names. 
Table 4. Elements of the offer of food products and catering services in the respondents' behaviour

\begin{tabular}{|c|c|c|c|}
\hline Specification & Elements of food products offer/gastronomy offer & $\begin{array}{l}\text { Importance } \\
\text { - average* }\end{array}$ & $\begin{array}{c}\text { Use } \\
\text { - average** }\end{array}$ \\
\hline \multirow{4}{*}{$\begin{array}{l}\text { Everyone is } \\
\text { an expert }\end{array}$} & Informing about the composition of the product / meal & 5,84 & 5,28 \\
\hline & Informing about the sugar content & 5,33 & 4,55 \\
\hline & Informing about the preservatives content & 5,20 & 4,52 \\
\hline & Informing about the fat content & 5,03 & 4,43 \\
\hline \multirow{3}{*}{$\begin{array}{l}\text { I can look } \\
\text { after myself }\end{array}$} & Informing about the calorie content & 4,93 & 4,66 \\
\hline & Informing about the vitamins content & 4,80 & 3,29 \\
\hline & Informing about the presence of allergens & 4,76 & 3,07 \\
\hline \multirow{4}{*}{$\begin{array}{l}\text { Back to } \\
\text { basics for } \\
\text { status }\end{array}$} & Informing about the presence of carbohydrates & 4,68 & 3,48 \\
\hline & Informing about the salt presence & 4,57 & 3,86 \\
\hline & Informing about the lactose presence & 4,47 & 3,96 \\
\hline & Informing about the gluten presence & 4,25 & 3,61 \\
\hline \multirow{3}{*}{$\begin{array}{l}\text { Conscious } \\
\text { consumer }\end{array}$} & Company commitment to people who need help & 4,58 & 4,02 \\
\hline & Informing about ways of preventing food waste & 4,02 & 3,60 \\
\hline & Informing about ways of sharing food & 4,01 & 3,61 \\
\hline \multirow{6}{*}{$\begin{array}{l}\text { Efficiency- } \\
\text { drive lifestyle }\end{array}$} & $\begin{array}{l}\text { The possibility of food / meal delivery } \\
\text { to the indicated place }\end{array}$ & 4,54 & 4,58 \\
\hline & Availability of small packages & 4,14 & 3,48 \\
\hline & An extensive offer of ready-to-eat dishes & 3,66 & 4,01 \\
\hline & A proposition of how to prepare a meal & 3,84 & 3,30 \\
\hline & The possibility of tasting products / dishes & 3,77 & 3,72 \\
\hline & Suggestions on how to serve a meal & 3,47 & 2,94 \\
\hline \multirow[t]{2}{*}{$\begin{array}{l}\text { I can look } \\
\text { after myself }\end{array}$} & $\begin{array}{l}\text { An extensive offer of bio, eco, natural and gluten free } \\
\text { products / dishes }\end{array}$ & 4,02 & 3,50 \\
\hline & Availability of ecological packaging & 3,95 & 3,29 \\
\hline \multirow{4}{*}{$\begin{array}{l}\text { I want a } \\
\text { plastic-free } \\
\text { world }\end{array}$} & $\begin{array}{l}\text { The possibility of composing individualized meals by the } \\
\text { customer }\end{array}$ & 4,01 & 3,40 \\
\hline & The possibility of planning a list of meals & 3,92 & 3,27 \\
\hline & Ability to draw up a shopping list & 3,88 & 3,55 \\
\hline & Calorie calculator & 3,86 & 3,48 \\
\hline \multirow{2}{*}{$\begin{array}{l}\text { Digitally } \\
\text { together }\end{array}$} & Sharing mobile applications & 3,86 & 3,10 \\
\hline & Enterprises' activity on social networks & 3,75 & 3,53 \\
\hline \multirow{3}{*}{$\begin{array}{l}\text { I can look } \\
\text { after myself } \\
\text { Efficiency- } \\
\text { drive lifestyle }\end{array}$} & Possibility of using the "box" diet & 3,73 & 3,04 \\
\hline & Dietician advice & 3,67 & 3,05 \\
\hline & An extensive offer of vegetarian / vegan products / dishes & 3,32 & 2,71 \\
\hline \multirow{3}{*}{$\begin{array}{l}\text { The world is } \\
\text { a game }\end{array}$} & Competitions for clients & 3,41 & 2,48 \\
\hline & Clients' clubs & 3,27 & 3,53 \\
\hline & Culinary workshops / games for customers & 2,90 & 3,99 \\
\hline
\end{tabular}

* assessment of significance was made on a scale from 1 to 7,1 - definitely not important; 7- definitely important

** the frequency of use was declared on a scale of 1 to 7,1 - never; 7-always

Source: Authors' own elaboration based on field research.

Consumer behaviour on the food market can be recognized by identifying the importance of individual elements of the food offer and the frequency of their use. The respondents' declarations indicate the importance of many of these elements (Table 4). In particular, consumers exhibit behaviour typical for trends described as "everyone is an expert", "I can take care of myself" and "return to the sources". It is important for 
customers to have the information that allows identification and evaluation of the product, especially information that is useful in the consumer choices of healthy and diet food / dishes. Until now, despite the importance they attach to this information, it is used differently by the surveyed consumers.

The surveyed representatives of generation Y most often consider activities that fit in the "conscious consumer" trend (company commitment to people who need help, informing about ways of sharing food and preventing its waste) to be of average importance. These are consumers for whom time is important - typical for the economy of rush - which is manifested mainly by providing meals in the place where they are staying.

\section{Summary}

The results of the research and analysis show that the $\mathrm{Y}$ generation (described as "yummy") is an extremely important entity on the food market - large in numbers, young, innovative, active, fast, demanding and certainly exceptional and very important for food supply entities - production companies, retailers and gastronomy. The behaviour of this group of consumers determine contemporary trends on the market and the necessity to undertake activities consistent with these trends in terms of the offer, its availability, as well as diversity and price. Opinions that the millennials so willingly share, photos of dishes that are enthusiastically disseminated in social media can be crucial for the success of a given retailer or catering place.

The behaviour of the Y generation, both those identified and anticipated, cause and will cause serious changes in the behaviour of the supply entities, such as limiting / eliminating artificial ingredients, non-organic packaging, enriching the offer with local and exotic products - typical for countries from different parts of the world, shortening the list of ingredients, simplifying dishes. Introducing new solutions turns out to be what $\mathrm{Y}$ generation expects. These changes are to be fast, adequate to the needs of customers and beneficial for them.

"Yummy" consumers are also trying to make rational decisions related to nutrition they pay attention to quality, and are willing to pay more for a good product adapted to their needs. New technologies are for generation Y absolutely natural, basic and indispensable in everyday life, without which it is impossible to function. At the same time, more and more often they strive to set the limits of their privacy, they value offline contacts and attribute high value to people-to-people contacts, which can become a chance for small stores where the customer is not anonymous.

Generation "yummy" uses a variety of dining options, eating at the catering place or ordering meals home. Often, they also have a passion for self-catering and eating at home. Millennials have a very rich, varied and innovative menu. They use a variety of dining options, preferring "casual food", "slow food", without giving up on "fast food". The respondents most often declare buying meals in gastronomic places, which are commonly perceived as offering fast and unhealthy food. The diagnosis of the gastronomic offer of such establishments, however, indicates a significant diversification of their offer, in particular its enrichment with healthy, dietary and fast meals, which are appreciated by representatives of generation Y. On the food market, information about 
the composition of products and dishes is very important to them and they most often use such information.

The results of direct research also indicate that among 10 trends of consumer behaviour expected for 2019, the respondents are most in line with the trend "everyone is an expert", "I can take care of myself" and "return to the sources". It should be underlined that the trends described in the theoretical part concerning generation $\mathrm{Y}$ on the food market are not clearly visible in the results of direct research. This may be related to the nature of the conducted research, the research technique used (inability to deepen statements and their declarativeness) and the sample size.

\section{Bibliography}

Angus A., Westbrook G., Top 10 Global Consumer Trends 2019. Euromonitor International, 2019 Baran M., Kłos M., Pokolenie Y - prawdy i mity w kontekście zarzqdzania pokoleniami, Marketing i Rynek 5/2014

Bartlett M., Analyst: understanding what shapes generation can help the ... . Credit Union Journal, No. 8(21)/2004

Bywalec Cz., Konsumpcja a rozwój gospodarczy i społeczny, C.H.Beck, Warszawa 2010,s.195

Dalton P., Managing the generation. ABA Washington News, No. 11(19)/2003

Gołąb-Andrzejak E., Konsumenci pokolenia $Y$ - nowe wyzwanie dla komunikacji marketingowej, Handel Wewnętrzny 2016/2

Kisiel P., Millenialsi - nowy uczestnik życia społecznego, Studia Socialia Cracoviensia $8 \mathrm{nr}$ 1/2016

Kucharska B., Innowacje $w$ handlu detalicznym $w$ kreowaniu wartości dla klienta. Uniwersytet

Ekonomiczny w Katowicach, Katowice 2014

Kucharska B., Food in retailers' commercial offer - possibilities of building relationships with consumers, Olsztyn Economic Journal, nr 14/2019

Miller R.K., Washington K., Consumer Behavior 2011: Millennial Consumers, Richard K. Miller and Associates (RKMA), Loganville 2011

Polski rynek handlu spożywczego w 2010-2020 roku. Roland Berger Report, 2016

Rich M., Millennial students and technology choices for information searching. The Electronic Journal of Business Research Methods, No. 6(1)/2008.

Sowa I., Nowe trendy $w$ zachowaniach młodych konsumentów wyzwaniem dla wspótczesnego handlu. Zeszyty Naukowe Uniwersytetu Szczecińskiego nr 777. Problemy Zarządzania, Finansów i Marketingu nr 32/2013

[www1] https://encyklopedia.pwn.pl/haslo/pokolenie;3959194.html

[www2] https://poradnikprzedsiebiorcy.pl/-pokolenia-w-pracy-pokolenie-y

[www3] http://www.portalspozywczy.pl/handel/wiadomosci/glodny-jak-millenials-czyli-jakpokolenie-y-kupuje-zywnosc, 145251.html;

[www4] http://www.odzywianie.info.pl/przydatne-informacje/artykuly/art,jak-odzywia-siepokolenie-millenialsow.html;

[www5] http://www.national-geographic.pl/ludzie/obsesja-jedzenia-kim-sa-ludzie-z-pokoleniamniam

[www6] http://www.poradnikhandlowca.com.pl/aktualnosci-gospodarka/kpmg-milenialsi-szansaczy-zagrozenie-dla-handlu-lokalnego;

[www7] https://www.polskieradio.pl/42/273/Artykul/1729078,Millenialsi-lubia-nowosci-

produkty-regionalne-i-rzemieslnicze-oraz-polskie.html

[www8] http://www.portalspozywczy.pl/handel/wiadomosci/pokolenie-y-to-bardzo-swiadomikonsumenci,137873.html 


\section{Streszczenie}

Celem artykułu jest identyfikacja zachowań pokolenia $\mathrm{Y}$ na rynku żywności kontekście dominujących trendów konsumenckich. Realizacji celu artykułu posłużyły studia literaturowe, informacje pochodzące $\mathrm{z}$ czasopism branżowych oraz badania bezpośrednie przeprowadzone przez autorów artykułu. Rozpoznania trendów konsumenckich dokonano na podstawie wtórnych źródeł informacji, wykorzystując również raport Top 10 Global Consumer Trends 2019 Euromonitor International. Raport stał się także inspiracją do podjęcia badań bezpośrednich, które zostały zrealizowane techniką ankiety audytoryjnej wśród przedstawicieli pokolenia Y. Wyniki przeprowadzonych badań i analiz wskazuja, że pokolenie Y określane jako „mniam” to niezwykle ważny podmiot na rynku żywności - duży liczebnie, młody, innowacyjny, aktywny, szybki, wymagający, wyjątkowy oraz bardzo ważny dla podmiotów podaży na rynku żywności. To zachowania tej grupy konsumentów wyznaczają współczesne trendy na rynku i konieczność podejmowania działań zgodnych $\mathrm{z}$ tymi trendami w zakresie oferty, jej dostępności, a także różnorodności oraz ceny.

Słowa kluczowe: pokolenie $\mathrm{Y}$, zachowania konsumentów, rynek żywności, trendy JEL Code: D11 D12 J11

Information about authors:

\section{Dr Barbara Kucharska}

Dr Mirosława Malinowska

University of Economics in Katowice

Department of Markets and Consumption

ul. 1 Maja 50, 40-287 Katowice

e-mail: miroslawa.malinowska@ue.katowice.pl, ORCID 0000-0001-7467-2502

e-mail: barbara.kucharska@ue.katowice.pl, ORCID 0000-0003-0669-3330 